Jurnal Ekonomi Syariah Darussalam

Vol I No I Agustus 2020, ISSN: 2745-8407

\title{
KERJASAMA MARO PENGOLAHAN SAWAH DALAM PERSPEKTIF HUKUM EKONOMI ISLAM DI DESA TAMANAGUNG KECAMATAN CLURING KABUPATEN BANYUWANGI
}

\author{
Mamlukah $^{1}$, Devi Wahyuningtyas ${ }^{2}$ \\ Institut Agama Islam Darussalam Blokagung Tegalsari Banyuwangi \\ Email: mamlukhah@iaida.ac.id ${ }^{1}$, Devityas96gmail.com²
}

\begin{abstract}
This research aims to find out how the practice of collaborating with rice processing in the Tamanagung Village, Cluring District, Banyuwangi, and knowing how to practice the cooperation with processing of maro in The Tamanagung Village, Cluring District, Banyuwangi the perspective of Islamic economic law. The type used in this study is descriptive analysis, which describes the data that researchers collect both from observations, interviews and documentation. Data analysis uses interactive model analysis techniques. The results of the study are the collaboration carried out by the owner of the paddy field and the paddy farmer, the paddy owner only provides land only, while the paddy cultivator is burdened with material capital and labor to work on the paddy. The practice of maro processing in paddy fields in Tamanagung Village, Cluring District, Banyuwangi Regency is included in the mukhabarah contract. The profit sharing mechanism uses the bawon system (fee). If 100\% of the yield is obtained, $20 \%$ will be given to the cultivators of the paddy fields, while the remaining $80 \%$ of the deduction will be collected between the two parties where each party will get an equal $40 \%$ yield.
\end{abstract}

\section{Keywords: Cooperation, Maro, Paddy Processing, Islamic Economic Law}

\begin{abstract}
Abstrak
Penelitian ini bertujuan untuk mengetahui bagaimana praktik kerjasama maro pengolahan sawah di Desa Tamanagung Kecamatan Cluring Kabupaten Banyuwangi serta mengetahui bagaimana praktik kerjasama maro pengolahan sawah di Desa Tamanagung Kecamatan Cluring Kabupaten Banyuwangi dalam perspektif hukum ekonomi Islam. Jenis yang digunakan dalam penelitian ini adalah analisis deskriptif, yaitu menggambarkan data-data yang peneliti kumpulkan baik dari hasil observasi, wawancara maupun dokumentas. Analisis data menggunakan teknik analisis interaktif model. Hasil penelitian yakni kerjasama yang dilakukan oleh pemilik sawah dan penggarap sawah, pemilik sawah hanya menyediakan lahan saja, sedangkan penggarap sawah yang yang dibebani modal materi maupun tenaga untuk menggarap sawah. Praktik kerjasama maro pengolahan sawah di Desa Tamanagung Kecamatan Cluring Kabupaten Banyuwangi termasuk kedalam akad mukhabarah. Mekanisme bagi hasilnya menggunakan sistem bawon (upah). Jika mendapat hasil 100\% maka 20\% akan diberikan kepada penggarap sawah, sedangkan sisa $80 \%$ pemotongan bawon akan dibagihasilkan antara kedua belah pihak di mana masing-masing pihak mendapat hasil sama rata 40\%.
\end{abstract}

Kata Kunci: Kerjasama, Maro, Pengolahan Sawah, Hukum Ekonomi Islam 
Jurnal Ekonomi Syariah Darussalam

Vol I No I Agustus 2020, ISSN: 2745-8407

\section{A. PENDAHULUAN}

Agama Islam merupakan agama yang komperhensif (rahmatan lil'alamin) dimana semua aspek kehidupan manusia telah diatur dalam sabda Rasulullah SAW. Islam mengatur kehidupan masyarakat baik itu berlaku secara individu maupun social, tidak dapat dipungkiri manusia merupakan makhluk sosial karena mereka tidak dapat bekerja sendiri dan masih membutuhkan pertolongan dari orang lain untuk kelangsungan hidupnya (Utami, 2017:87).

Kebutuhan akan kerjasama antara satu pihak dengan pihak lain guna meningkatkan taraf perekonomian dan kebutuhan hidup serta keperluan-keperluan lain tidak bisa diabaikan. Di antara beberapa manusia mempunyai modal akan tetapi tidak bisa mengelola usaha produktif atau bisa menjalankan usaha produktif namun ingin menolong orang lain yang kurang mampu, sehingga berinisiatif dengan cara mengalihkan sebagian dari modalnya kepada orang lain yang membutuhkan. Di sisi yang lain ditemui beberapa orang yang mempunyai kemampuan dan ahli dalam berusaha namun tidak memiliki cukup modal untuk menjalankan suatu usaha. Berdasarkan kenyataan tersebut, kerjasama sangat diperlukan, dengan bekerjasama itulah orang-orang yang taraf perekonomiannya tinggi dan orang-orang taraf perekonomiannya rendah akan sama-sama diuntungkan. Pihak yang mempunyai modal bisa memanfaatkan modalnya tersebut, begitu pula sebaliknya.

Persoalan muamalah merupakan persoalan yang senantiasa terjadi ditengahtengah masyarakat, sesuai dengan perkembangan dari peradaban umat Islam itu sendiri. Salah satu bidang muamalah yang sangat penting bagi masyarakat merupakan pertanian. Lahan pertanian bagi masyarakat dirasa sangat penting karena dengan lahan pertanian masyarakat bisa memenuhi kebutuhan hidup seharihari, lahan pertanian yang dimaksud adalah lahan yang yang digunakan untuk memproduksi tanaman maupun hewan ternak. Islam yang menganjurkan jika seorang memiliki tanah atau lahan pertanian dianjurkan harus mengelola dan memanfaatkannya. Pengolahan lahan pertanian tersebut dapat dilakukan dengan berbagai cara sebagaimana yang diajarkan dalam agama Islam, seperti halnya dengan cara diolah sendiri oleh sang pemilik lahan pertanian atau dengan cara kerjasama dengan orang lain untuk menggarapnya. Di dalam Islam kerjasama lahan pertanian dinamakan dengan Mukhabarah, muzara'ah, musaqoh (Utami, 2017:23). 
Jurnal Ekonomi Syariah Darussalam

Vol I No I Agustus 2020, ISSN: 2745-8407

Kabupaten Banyuwangi memiliki 24 Kecamatan, salah satunya Kecamatan Cluring, yang terletak diantara Kecamatan Srono dan Kecamatan Gambiran. Sumber ekonomi yang mendukung di Kecamatan Cluring merupakan pertanian, hal ini terbukti dengan mayoritas penduduknya bekerja dibidang pertanian. Luas lahan sawah yang ada di Kecamatan Cluring mencapai kisaran 4.055 dirinci menurut jenis pengairan Kecamatan Kabupaten Banyuwangi pada tahun 2018, Kecamatan Cluring menempati peringkat 3 (ketiga) setelah Kecamatan Purwoharjo dan Tegaldlimo. Kecamatan Cluring memiliki 9 (Sembilan) desa. Salah satu desa di Kecamatan Cluring yang mayoritasnya petani merupakan Desa Tamanagung. Berdasarkan profil Desa Tamanagung pada tahun 2018 potensi sumber daya alam sektor pertanian yang sudah dikelola meliputi hasil: Padi, palawija, sayuran, dan buah-buahan. Hasil padi rata-rata tiap tahun mencapai kisaran 6,5 ton/Ha, dan palawija meliputi kedelai, kacang tanah, kacang hijau, jagung, ubi jalar, dan ubi kayu sekitar 1,5 Ton/Ha, terbukti hasil pertanian terbanyak merupakan padi.

Di zaman yang serba canggih dan semakin pesatnya pembangunan struktur wilayah, ekonomi dan politik, banyak orang yang memiliki sawah akan tetapi kurang mampu dalam mengolah lahan pertaniannya. Hal ini disebabkan juga karena para pemilik sawah tidak sempat untuk mengolah sawah dikarenakan sibuk dengan pekerjaan lain. Oleh sebab itu banyak pemilik sawah yang bekerjasama dengan orang lain untuk mengolah sawah mereka, termasuk masyarakat di Desa Tamanagung Kecamatan Cluring Kabupaten Banyuwangi. Kerjasama yang dilakukan masyarakat Desa Tamanagung Kecamatan Cluring Kabupaten Banyuwangi pada umumnya tidak tertuliskan namun hanya secara lisan yang mana pemilik sawah hanya mempercayakan penggarap untuk mengolah sawahnya sampai mendapatkan hasil panen. Kerjasama dilandasi rasa tolong menolong, dilatarbelakangi oleh keadaan saling membutuhkan, atas dasar sukarela bukan paksaan, didukung pula oleh rasa kekeluargaan di antara kedua belah pihak antara pemilik sawah dan penggarap. Kerjasama tersebut dikenal dengan sebutan maro di kalangan masyarakat Desa Tamanagung Kecamatan Cluring Kabupaten Banyuwangi (Saminu, 2019:13).

Menurut wawancara dengan Bapak Saminu, kerjasama maro sudah sejak tahun 1968 diterapkan masyarakat Desa Tamanagung Kecamatan Cluring Kabupaten 
Jurnal Ekonomi Syariah Darussalam

Vol I No I Agustus 2020, ISSN: 2745-8407

Banyuwangi. Pelaksanaan kerjasama ini pada umumnya berdasarkan dengan kebiasaan masyarakat yang telah ada. Disamping itu faktor yang mendorong masyarakat Desa Tamanagung melakukan kerjasama ini adalah adanya pihak yang mempunyai kemampuan atau keahlian dalam hal mengolah sawah namun tidak memiliki sawah yang akan dikerjakan, ada pula yang memiliki sawah tetapi tidak mempunyai keahlian untuk mengelolanya. Sehingga jika kerjasama ini diterapkan akan saling menguntungkan masing-masing pihak. Istilah maro dimana hasil keuntungan akan dibagi dua sesuai kesepakatan bersama. Pembagian hasil dilakukan ketika sudah waktunya panen. Hasil panen tersebut akan dibagihasilkan setelah ada pemotongan (bawon) biaya perawatan tanaman yang akan diberikan kepada penggarap sawah. Dalam pelaksanaan praktiknya pemilik sawah tidak mengeluarkan modal sama sekali, baik itu modal materi maupun modal tenaga. Semua akan dibebankan kepada penggarap sawah, pemilik sawah hanya bermodalkan tanah saja.

Kenyataan praktiknya, ada beberapa kejanggalan seperti pemilik sawah yang kadang tidak baik, mereka tidak memberikan upah untuk perawatan tanaman yang seharusnya diberikan kepada penggarap sawah pada saat panen. Sehingga dirasa kurang adil bagi penggarap sawah yang seharusnya mendapatkan upah tersebut (Saminu, 2019:28).

Ajaran Islam sendiri akad yang dilakukan dalam aktivitas muamalah harus melahirkan rasa keadilan yang berimbang antar sesama. Seseorang tidak diperbolehkan melaksanakan transaksi yang mengandung unsur tipuan, dan pengambilan hak atas orang lain.

Berdasarkan uraian latar belakang di atas dapat dirumuskan masalah penelitian sebagai berikut: 1) Bagaimana Praktik Kerjasama Maro Pengolahan Sawah di Desa Tamanagung Kecamatan Cluring Kabupaten Banyuwangi? 2) Bagaimana Praktik Kerjasama Maro Pengolahan Sawah di Desa Tamanagung Kecamatan Cluring Kabupaten Banyuwangi dalam Perspektif Hukum Ekonomi Islam?

\section{B. LANDASAN TEORI}

\section{Tinjauan tentang Maro}

Sistem maro adalah proses bagi hasil antara pemilik lahan dengan penggarap lahan dimana masing-masing mendapatkan bagian $1 / 2$ dari seluruh hasil pengolahan 
Jurnal Ekonomi Syariah Darussalam

Vol I No I Agustus 2020, ISSN: 2745-8407

lahan pertanian. Semua jenis tanaman yang ditanam oleh penggarap dibagi hasilkan seluruhnya. Bagi hasil menurut istilah adalah suatu sistem yang meliputi tata cara pembagian hasil usaha antara penyedia dana dan pengelola dana. Bagi hasil merupakan kesepakatan antara kedua belah pihak yaitu pemilik tanah dan penggarap tanah, atas dasar sukarela dan bukan paksaan. Perjanjian bagi hasil disamping dilatarbelakangi oleh keadaan saling membutuhkan, atas dasar sukarela, bukan paksaan juga dapat pula didorong oleh rasa kekeluargaan dan saling tolongmenolong diantara pemilik tanah dengan penggarap. Masyarakat telah lama melakukan perjanjian bagi hasil secara turun temurun, serta pada umumnya pelaksanaan bagi hasil sesuai kebiasaan yang telah ada (Wulandari, 2019:13).

Secara bahasa bagi hasil ialah transaksi pengolahan bumi dengan (upah) sebagian hasil yang keluar daripadanya. Praktek muzaraah berkaitan dengan pembagian hasil, dengan kata lain disebut dengan bagi hasil pertanian. Bagi hasil yang biasanya kesepakatan masyarakat petani dalam akad pada umumnya di kenal dengan sebutan mertelu, mrapat, dan maro. Perjanjian diistilahkan dengan maro, dimana pemilik dan penggarap sepakat hasilnya akan dibagi dua dengan ketentuan pemilik menyerahkan lahan dan modal produksi seperti bibit padi dan lainnya, sedangkan penggarap menyediakan alat dan tenaga (Bustomi, Setyawan dkk, 2018:06).

Bagi hasil dalam pertanian merupakan bentuk pemanfaatan tanah di mana pembagian hasil terdapat dua unsur produksi, yaitu modal dan kerja dilaksanakan menurut perbandingan tertentu dari hasil tanah maro merupakan sistem bagi hasil pertanian dengan perimbangan bagi hasilnya adalah atau $1: 1$. Maksudnya $1 / 2$ bagian untuk pemilik tanah (pemodal) dan $1 / 2$ bagian untuk penggarap (Muttalip, 2015:91).

Berdasarkan definisi diatas dapat disimpulkan bahwa maro adalah perjanjian/kerjasama bagi hasil di bidang pertanian yang mana menjadi kebiasaan masyarakat pedesaan dilakukan berdasarkan rasa tolong menolang bukan paksaan, mekanisme pembagian hasilnya adalah masing-masing pihak mendapatkan keuntungan hasil panen yaitu 50:50.

\section{Hukum Ekonomi Islam}

Hubungan hukum dengan ekonomi bukan hubungan satu arah, tetapi hubungan timbal balik dan saling memengaruhi. Kegiatan ekonomi yang tidak didukung oleh 
Jurnal Ekonomi Syariah Darussalam

Vol I No I Agustus 2020, ISSN: 2745-8407

hukum akan mengakibatkan terjadi kekacauan, sebab apabila para pelaku ekonomi dalam mengajar keuangan tidak dilandasi dengan norma hukum maka akan menimbulkan gangguan dalam kegiatan ekonomi. Hukum dan ekonomi ibarat dua sisi mata uang yang tidak dapat dipisahkan dan saling melengkapi (Manan, 2012:378)

Hukum ekonomi Islam menganut prinsip bahwa suatu kemitraan atau perkongsian (syirkah) dianggap sah kalau kemitraan tersebut sudah memenuhi rukun dan syarat yang telah ditetapkan dalam hukum Islam. Hukum Islam ada 5 yaitu wajib, haram, sunah, mubah dan makruh. Menurut Manan (2012:114) rukun kemitraan atau perkongsian (syirkah) dalam syariat Islam ada tiga macam yaitu adanya shigat (ijab qabul) apabila sudah terjadi kesepakatan terhadap suatu hal yang diperjanjikan, pihak-pihak yang melakukan kemitraan orang-orang yang dibenarkan oleh syariat Islam untuk melakukan kemitraan) dan pokok pekerjaan (bidang usaha yang dikerjakan). Disamping itu juga diperlukan syarat-syarat yang harus ada dalam suatu kemitraan yaitu orang yang melakukan kemitraan harus sehat akalnya, dewasa, baligh, dengan hendaknya sendiri dan barang yang dibuat modal perjanjian harus bernilai dan halal.

\section{Kerjasama dalam Islam}

Hubungan antara manusia satu dengan manusia lain dalam memenuhi kebutuhan, harus terdapat aturan yang menjelaskan hak dan kewajiban keduanya berdasarkan kesepakatan. Proses untuk membuat kesepakatan dalam kerangka untuk memenuhi kebutuhan keduanya, lazim disebut proses untuk berakad atau melakukan kerjasama. Pada dasarnya transaksi bisnis kerjasama yang menjadi inti dalam fiqih muamalah adalah transaksi bagi hasil. Berikut ini adalah beberapa transaksi kerjasama bagi hasil yaitu:

\section{Syirkah/Musyarakah}

Syirkah menurut bahasa menurut bahasa adalah percampuran, yaitu percampuran salah satu dari dua harta dengan yang lain tidak membedakan satu sama lain. Menurut Ulama syafi'iyah berpendapat bahwa syirkah merupakan tetapnya hak atas suatu barang bagi dua orang atau lebih secara bersama-sama. (Rozalinda, 2017:191).

Ulama Malikiyah mendefinisikan syirkah ialah izin untuk bertasruf bagi kedua 
Jurnal Ekonomi Syariah Darussalam

Vol I No I Agustus 2020, ISSN: 2745-8407

orang yang berserikat terhadap harta keduanya dengan tetapnya hak tasruf bagi masing-masing keduanya. Menurut golongan Hanafiyah adalah ungkapan terhadap akad antara orang yang berserikat tentang modal dan riba. Firman Allah dalam AlQur'an Surat An-Nisa ayat 12 berbunyi syirkah:

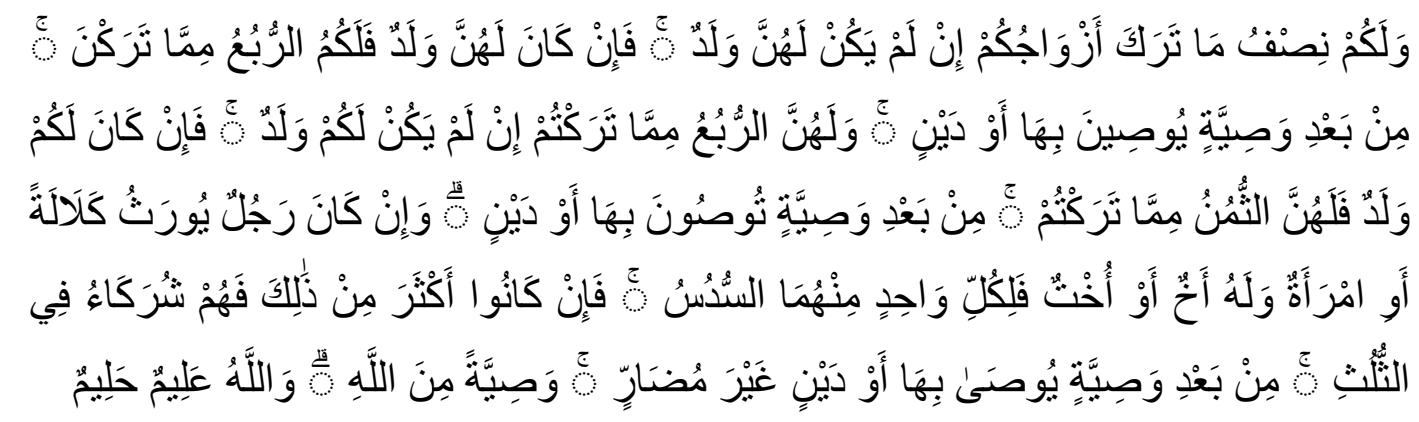

Artinya: "Dan bagimu (suami-suami) seperdua dari harta yang ditinggalkan oleh isteri-isterimu, jika mereka tidak mempunyai anak. jika isteri-isterimu itu mempunyai anak, Maka kamu mendapat seperempat dari harta yang ditinggalkannya sesudah dipenuhi wasiat yang mereka buat atau (dan) seduah dibayar hutangnya. Para isteri memperoleh seperempat harta yang kamu tinggalkan jika kamu tidak mempunyai anak. Jika kamu mempunyai anak, Maka Para isteri memperoleh seperdelapan dari harta yang kamu tinggalkan sesudah dipenuhi wasiat yang kamu buat atau (dan) sesudah dibayar hutang-hutangmu. Jika seseorang mati, baik lakilaki maupun perempuan yang tidak meninggalkan ayah dan tidak meninggalkan anak, tetapi mempunyai seorang saudara laki-laki (seibu saja) atau seorang saudara perempuan (seibu saja), Maka bagi masingmasing dari kedua jenis saudara itu seperenam harta. Tetapi jika saudara-saudara seibu itu lebih dari seorang, Maka mereka bersekutu dalam yang sepertiga itu, sesudah dipenuhi wasiat yang dibuat olehnya atau sesudah dibayar hutangnya dengan tidak memberi mudharat (kepada ahli waris (Allah menetapkan yang demikian itu sebagai) syari'at yang benar-benar dari Allah, dan Allah Maha mengetahui lagi Maha Penyantu" (Departemen Agama RI, 2009:79).

Ayat ini menjelaskan bahwa Islam membenarkan seorang Muslim berdagang dan dan berusaha secara perorangan atau menggabungkan modal dalam bentuk perkongsian tidak dapat ditangani sendiri. Untuk itu, ia membutuhkan banyak modal, tenaga, dan ketrampilan. Dengan menggabungkan berbagai kekuatan tersebut, memungkinkan usaha dapat berjalan lancar (Rozalinda, 2017:193).

Kompilasi hukum ekonomi syariah yang dikeluarkan Mahkamah Agung Republik Indonesia, konsep syirkah adalah kerjasama yang dapat dilakukan antara dua pihak pemilik modal atau lebih untuk melakukan usaha bersama dengan jumlah modal yang tidak sama, masing-masing pihak berpartisipasi dalam perusahaan, dan 
Jurnal Ekonomi Syariah Darussalam

Vol I No I Agustus 2020, ISSN: 2745-8407

keuntungan atau kerugian dibagi sama atau atas dasar proporsi modal (Kompilasi Hukum Ekonomi Syari- ah, MA, 2003:43).

Berdasarkan definisi yang telah diuraikan diatas secara hakikat mengacu bahwa syirkah adalah kerjasama antara dua orang atau lebih dalam suatu usaha dimana keduaanya sama-sama memasukkan modal dalam usaha kemudian, keuntungan dibagi bersama sesuai dengan kesepakatan dan kerugian ditanggung bersama-sama.

\section{Mudharabah}

Mudharabah adalah suatu akad kerjasama antara pemilik modal (shahibul mal) dengan pengusaha (mudahrib), dimana pemilik modal menyerahkan modal kepada mudharib untuk diproduktifkan. Kemudian laba yang diperoleh dibagi sesuai dengan kesepakatan.

\section{Muzaraah dan Mukhabarah}

Kerjasama dalam lahan pertanian adalah suatu bentuk syirkah, di mana satu pihak menyediakan lahan pertanian dan pihak yang lain sebagai penggarapan tanah berdasarkan prinsip bagi hasil. Secara bahasa muzaraah adalah mufallah min azzar'i (bekerja sama di bidang pertanian). Muzaraah dan mukhabarah merupakan kerjasama antara pemilik sawah/ladang petani berdasarkan bagi hasil. Di Indonesia kerjasama lahan pertanian berdasarkan bagi hasil ini dikenal dengan istilah "Paroan Sawah", atau "Paduoan", atau Patigoan" (Rozalinda, 2017:219).

Setelah diketahui definisi-definisi di atas, dapat dipahami bahwa mukhabarah dan muzaraah ada persamaan dan ada pula perbedaan. Persamaannya ialah mukhabarah dan muzaraah terjadi pada pada peristiwa yang sama, yaitu pemilik tanah menyerahkan tanahnya kepada orang lain untuk dikelola. Perbedaanya ialah pada modal, bila modal berasal dari pengelola, disebut mukhabarah, dan bila modal dikeluarkan dari pemilik tanah muzah (Suhendi, 2016:155-156).

\section{Musaqah}

Musaqah menurut bahasa, berarti mufa'alah min as-saqa (bekerja sama dalam masalah siraman). Menurut istilah adalah penyerahan tanaman kepada orang yang menyiramnya berdasarkan bag hasil (hasil tanaman untuk keduanya). Musaqah menurut ulama Syafi'iyah dalam bukunya Rozalinda ialah pemilik pohon kurma dan anggur memperkerjakan seseorang untuk menyiram, memelihara, dan menjaga 
Jurnal Ekonomi Syariah Darussalam

Vol I No I Agustus 2020, ISSN: 2745-8407

dan sejenisnya pohon-pohon kurma dan anggurnya atas dasar pekerja memperoleh bagian dari hasil pohon kurma dan anggur tersebut. Menurut Hanabilah dalam bukunya Rozalinda menyatakan bahwa musaqah ialah pemilik menyerahkan tanah pertanian berupa kurma tau pohon yang mempunyai buah yang dapat dimakan dengan prinsip bagian tertentu dari buahnya (bagi hasil) seperdua atau sepertiga (Rozalinda, 2017:225). Demikian musaqah merupakan kerjasama antara pemilik kebun dengan petani penggarap pada waktu tertentu agar ia memelihara, dan menjaganya sampai tanaman itu menghasilkan berdasarkan prinsip bagi hasil.

\section{Penelitian Terdahulu yang Relevan}

Penelitian-penelitian terdahulu berfungsi sebagai pendukung dalam melakukan penelitian. Terdapat beberapa penelitian relavan dengan penelitian ini, diantaranya sebagai berikut: Yeni Nurhayati pada tahun 2015 dengan judul "Maro (Penggarapan Sawah) Dalam Perspektif Ekonomi Islam (Studi Kasus Kesesuaian dengan Sistem Muzara'ah di Desa Atari Indah Kecamatan Lalembu Kabupaten Konawe Selatan)". Penelitian Fakultas Ekonomi dan Bisnis Islam Institut Agama Islam Negeri (IAIN) Kendari, dari hasil penelitian ini diketahui bahwa terdapat sistem muzara'ah yang syarat nilai-nilai Islam yang baik dalam hal akad, penghasilan, serta berakhirnya akad muzara'ah. Serta terdapat kendala-kendala yang dihadapi oleh masyarakat seperti kesalahpahaman, ketidakcocokan, kurang komunikasi, dan keegoisan. Adapun cara penyelesainnya dilakukan dengan cara kekeluargaan atau musyawarah. Perbedaan dengan penelitian ini adalah peneliti menggunakan jenis penelitian studi kasus dengan pendekatan kualitatif dan menggunakan analisis interaktif, sedangkan persamaannya adalah sama-sama membahas tentang maro penggarapan sawah dalam perspektif ekonomi Islam

Restu Windi Utami pada tahun 2017, yang berjudul "Tinjauan Hukum Islam Terhadap Sistem Maro dalam Kerjasama Pengolahan Lahan Pertanian di Desa Tribuana Panggelan Banjarnegara”, penelitian IAIN Purwokerto, adapun hasil penelitian menurut hukum Islam adalah parktik sistem maro dalam kerjasama pengolahan lahan pertanian di Desa Tribuana Kecamatan Banjarnegara termasuk dalam akad mukhabarah. Akad mukhabarah dalam kerjasama ini sah karena sesuai dengan rukun dan syarat mukhabarah. Selain itu kerjasama tersebut dianggap bermanfaat karena memberikan pekerjaan kepada orang lain sehingga dapat 
Jurnal Ekonomi Syariah Darussalam

Vol I No I Agustus 2020, ISSN: 2745-8407

memenuhi kebutuhan hidup dari masing-masing pihak yang bekerjasama. Jadi sistem maro dalam kerjasama pengolahan lahan pertanian di Desa Tribuana Kecamatan Banjarnegara dikatakan sah dan dibenarkan secara hukum Islam karena kedua pihak saling meridhai dan saling merelakan. Perbedaan dalam penelitian yang kami lakukan adalah peneliti menggunakan jenis penelitian studi kasus, sedangkan persamaannya adalah sama-sama membahas tentang kerjasama pengolahan lahan pertanian maro.

\section{METODE PENELITIAN}

\section{Jenis Penelitian}

Jenis penelitian yang digunakan dalam penelitian ini adalah studi kasus yang single-case desing (desain kasus tunggal), dengan pendekatan penelitian kualitatif. Studi kasus, yang digali adalah entitas tunggal atau kejadian (kasus) dari masa tertentu dan aktivitas (bisa berupa suatu program, kejadian, institusi atau kelompok sosial).

\section{Subjek dan Objek Penelitian}

Subjek dalam penelitian ini adalah yang menjadi informan yaitu pemilik sawah dan penggarap sawah di Desa Tamanagung Kecamatan Cluring Kabupaten Banyuwangi. Penelitian ini cukup mewawancarai tujuh informan yaitu 3 (tiga) pemilik sawah dan 4 (empat) penggarap sawah yang mengetahui praktik kerjasama maro pengolahan sawah di Desa Tamanagung Kecamatan Cluring Kabupaten Banyuwangi. Objek dari penelitian ini adalah praktik kerjasama maro pengolahan sawah di Desa Tamanagung Kecamatan Cluring Kabupaten Banyuwangi.

\section{Teknik Pengumpulan Data}

Dilihat dari segi cara atau teknik dan mekanisme pengumpulan data, teknik pengumpulan data dapat dilakukan dengan teknik observasi (pengamatan), interview (wawancara), dokumentasi, dan gabungan keempatnya. Dalam penelitian kualitatif, pengumpulan data dilakukan pada natural setting (kondisi yang alamiah), sumber data primer, dan teknik pengumpulan data lebih banyak pada observasi, wawancara, dan dokumentasi (Abdullah dan Saebani, 2014:204). Teknik pengumpulan data yang digunakan dalam penelitian ini adalah: Observasi, Wawancara, Dokumentasi. 
Jurnal Ekonomi Syariah Darussalam

Vol I No I Agustus 2020, ISSN: 2745-8407

\section{Teknik Analisis Data}

Teknik analisis dalam penelitian ini menggunakan teknik analisis interaktif model yang yang ditemukan oleh Miles dan Hubberman (1984). Bahwa aktifitas dalam analisis data kualitatif dilakukan secara interaktif dan berlangsung secara terus menerus sampai tuntas, sehingga datanya sudah jenuh (Sugiyono. 2015:246). Aktivitas dalam analisis data terdiri dari tiga jalur kegiatan yang terjadi secara bersamaan yaitu: reduksi data, penyajian data, dan penarikan kesimpulan/verifikasi.

\section{HASIL DAN PEMBAHASAN}

\section{Kerjasama Maro Pengolahan Sawah di Desa Tamanagung Kecamatan Cluring Kabupaten Banyuwangi}

Penelitian ini melibatkan 2 (dua) pihak narasumber, pihak tersebut adalah seseorang yang terlibat dalam praktik kerjasama maro pengolahan sawah di Desa Tamanagung Kecamatan Cluring Kabupaten Banyuwangi, yakni si pemilik sawah dan penggarap sawah. Sebagian besar pekerjaan masyarakat di Desa Tamanagung Kecamatan Cluring Kabupaten Banyuwangi berprofesi sebagai petani. Terbukti dengan luas lahan yang digunakan paling luas adalah lahan untuk pertanian. Jadi tidaklah heran jika masyarakat Desa Tamanagung Kecamatan Cluring Kabupaten Banyuwangi menerapkan praktik kerjasama dalam urusan pertanian meraka, terbukti dengan luasnya lahan yang digunakan untuk pertanian tersebut otomatis pemilik sawah di Desa Tamanagung Kabupaten Banyuwangi banyak pula. Hal ini sesuai dengan penelitian Muhammad Khoiruddin Ro'uf (2017) yang berjudul “Kerjasama Maro Sawah Sistem Gembreng Dalam Perspektif Hukum Islam” yang menyatakan bahwa kerjasama dengan cara bagi hasil merupakan salah satu kegiatan muamalah yang sering terjadi dikalangan masyarakat Indonesia khususnya dalam bidang pertanian.

Rata-rata para pemilik sawah merupakan seseorang yang berprofesi sebagai petani yang mengolah lahan mereka sendiri. Namun pada kenyataannya ada juga pemilik sawah yang berprofesi bukan sebagai petani dan juga tidak memiliki keahlian dalam bidang bertani. Sehingga untuk mengatasi masalah tersebut, mereka datang kepada seseorang yang bersedia untuk menggarap sawahnya. Apabila penggarap sawah menyetujui untuk menggarap sawah pemilik sawah dengan berbagai kesepakatan, kerjasama maro pengolahan sawah pun terjadi antara kedua 
Jurnal Ekonomi Syariah Darussalam

Vol I No I Agustus 2020, ISSN: 2745-8407

belah pihak. Kerjasama maro pengolahan sawah sudah lama diterapkan dikalangan masyarakat Desa Tamanagung Kecamatan Cluring Kabupaten Banyuwangi sehingga sudah menjadi kebiasaan. Menurut pemilik sawah di Desa Tamanagung Kecamatan Cluring Kabupaten Banyuwangi praktik kerjasama maro pengolahan sawah, pihak pemilik sawah tidak mengeluarkan modal sama sekali baik itu modal tenaga maupun materi, pemilik sawah hanya akan bermodal tanah yang akan digarap oleh seorang penggarap. Semua tanggungan modal materi maupun tenaga akan dibebankan kepada penggarap yang sudah bersedia menggarap sawah.

Hal ini sesuai dengan penelitian Muhammad Khoiruddin Ro'uf (2017) yang berjudul "Kerjasama Maro Sawah Sistem Gembreng Dalam Perspektif Hukum Islam" yang menyatakan bahwa sistem bagi hasil menjadi suatu yang penting terhadap orang orang mempunyai tenaga kerja tetapi tidak mempunyai lahan, sementara yang lain memiliki lahan tetapi tidak mempunyai modal dan tenaga kerja. Berdasarkan keadaan seperti ini saling membantu dan bekerjasama, maka hanya sistem bagi hasil yang merupakan cara efektif untuk menghasilkan lebih banyak tanah yang dapat diolah sehingga menguntungkan kedua belah pihak.

Kerjasama maro pengolahan sawah merupakan kerjasama yang dilakukan secara lisan saja dan tidak membutuhkan saksi. Hal ini dikarenakan bukan sewa atau gadai. Terdapat rukun dan syarat dalam kerjasama maro pengolahan sawah yang ada di Desa Tamanagung Kecamatan Cluring Kabupaten Banyuwangi, rukunnya adalah adanya perjanjian kerjasama maro pengolahan sawah sedangkan syaratnya adanya lahan yang diolah, ada orang yang menggarap dan ada pemilik sawah. Ada pula yang berpendapat rukun kerjasama maro pengolahan sawah tidak ada namun syaratnya kepercayaan, kejujuran, dan sama-sama saling menguntungkan tidak saling merugikan. Akan tetapi juga yang berpendapat bahwa rukun dan syarat kerjasama ini tidak ada.

Selang waktu melakukan kerjasama maro pengolahan sawah ditetapkan pada awal perjanjian. Namun ada juga pelaku kerjasama maro pegolahan sawah yang berpendapat bahwa tidak semua selang waktu kerjasama maro ditetapkan di awal perjanjian, terkadang juga diakhir perjanjian serta terserah pemilik sawah kapanpun mengambil alih sawah tersebut.

Ketika panen tiba penggarap sawah akan memberitahu pemilik sawah untuk 
Jurnal Ekonomi Syariah Darussalam

Vol I No I Agustus 2020, ISSN: 2745-8407

ikut serta pada saat panen dan penjualan hasil panen, setelah itu mekanisme bagi hasil panen dilakukan antara kedua belah pihak yakni pemilik sawah dan penggarap sawah. Hasil panen tersebut akan diambil bawon (biaya perawatan tanaman) yang akan diberikan kepada penggarap sawah. Sisa hasil pemotongan bawon (biaya perawatan tanaman) tersebut baru dibagihasilkan antara kedua belah pihak. Menggunakan sistem bawon karena sudah menjadi kebiasaan dari masyarakat sekitar. Jika mendapat hasil 100\%, 20\% akan dibagikan kepada penggarap sawah sebagai bawon, sisa 80\% akan dibagihasilkan untuk keduanya sehingga masingmasing akan mendapat 40\%. Pembagian hasil panen ini dirasa sudah sesuai yang diharapkan oleh kedua belah pihak karena sudah ditetapkan diawal melakukan kerjasama. Jika panen mengalami keuntungan maka keuntungannya akan dibagi antara kedua belah pihak. Begitu juga juga sebaliknya jika panen mengalami kerugian, maka kerugian akan ditanggung bersama.

Menurut pandangan masyarakat Desa Tamangaung Kecamatan Cluring Kabupaten Banyuwangi ada banyak keuntungan melakukan kerjasama maro pengolahan sawah. Bagi pemilik sawah sendiri mereka yang tidak perlu susah payah mengeluarkan modal baik itu materi dan tenaga, tetapi mendapatkan hasil panen. Mereka bisa lebih fokus untuk pekerjaan yang lain dikarenakan sawah mereka sudah ada yang menggarap. Pemilik sawah yang tidak memiliki keahlian dalam bertani pun akan angat terbantu dengan melakukn kerjasama ini, sawah mereka ada yang menggarap dan juga mendapatkan hasil. Selain itu keuntungan melakukan kerjasama maro pengolahan sawah bagi penggarap sawah yakni penggarap sawah yang tidak mempunyai sawah dapat mengolah sawah dengan keahlian mereka serta mendapatkan hasil. Dengan adanya kerjasama maro pengolahan sawah tersebut mereka yang hanya memiliki keahlian dalam bidang bertani akan mendapatkan pekerjaan. Penggarap sawah yang melakukan kerjasama maro pengolahan sawah akan mendapatkan hasil lebih banyak walaupun biaya yang dikeluarkan juga banyak.

Ketika ada keuntungan juga terdapat kerugian dalam melakukan kerjasama tersebut. Bagi pemilik sawah kerugian tersebut ialah pemilik sawah tidak bisa menetukan tanaman apa yang akan di tanam di sawah mereka, karena yang berpihak menentukan penggarap sawah, seandainya mereka ingin mendapatkan hasil panen 
Jurnal Ekonomi Syariah Darussalam

Vol I No I Agustus 2020, ISSN: 2745-8407

yang lebih dengan menanam tanaman yang bernilai jual tinggi, hal itu tidak diperbolehkan karena bukan berhak pemilik sawah. Kerugian juga dirasakan jika tanaman berkualitas jelek sehingga hasil panen pun sedikit serta pembagian hasilnya juga sedikit. Akan tetapi pemilik sawah mengetahui tanaman apa yang akan ditanam oleh penggarap sawah. Lain halnya kerugian yang dirasakan oleh penggarap sawah, mereka terkadang tidak puas dengan hasil dari pembagian hasil yang diterima. Mereka berpendapat bahwa kerugian dirasakan dalam hal tenaga seperti membajak sawah, matun (membersihkan rumput liar), tandur (menanam padi), memupuk tanaman, mengobat tanaman dan sebagainya. Menurut hasil wawancara dengan Bapak Suwadi (50) selaku penggarap sawah pekerjaan yang membutuhkan tenaga ini bukan termasuk dalam pembagian hasil bawon (biaya perawatan tanaman). Sehingga penggarap sawah merasa dirugikan dengan hal ini.

Pada kenyataannya telah terjadi kesepakatan antara kedua belah pihak dalam hal pembagian hasil, pembagian hasil sudah dinyatakan diawal terjadinya kerjasama, sehingga sudah sangat jelas bagaimana ketentuan bagi hasilnya dan penggarap sawah menyetujuinya. Jika penggarap sawah merasa dirugikan dengan ketentuan tersebut bukan karena kecurangan dari pemilik sawah melainkan karena sikap individual dari penggarap sendiri yang merasa kurang puas dengan hasil pembagian yang diterima.

Agar kegiatan dalam bermuamalah seseorang sejalan dengan ketentuan agama, ia harus menyelaraskan dengan prinsip-prinsip muamalah yang digariskan dalam ajaran Islam, adapun hal-hal yang menjadi prinsip dalam bermuamalah salah satunya adalah asas kerelaan. Setiap akad atau transaksi yang dilaksanakan dengan sesama manusia harus dilakukan atas dasar suka sama atau kerelaan, hal ini dilakukan agar dalam setiap transaksi tidak terjadi karena paksaan dan intimidasi pada salah satu pihak atau pihak lain (Rosalinda, 2017: 4-9).

Pada dasarnya masyarakat Desa Tamangung Kecamatan Cluring Kabupaten Banyuwangi sangat terbantu dengan adanya kerjasama maro pengolahan sawah, walaupun terkadang ada pihak-pihak yang merasa kurang puas dengan hasil pembagian hasil panen yang diterima walaupun sudah terjadi kesepakatan diawal perjanjian kerjasama. 
Jurnal Ekonomi Syariah Darussalam

Vol I No I Agustus 2020, ISSN: 2745-8407

Kerjasama Maro Pengolahan Sawah di Desa Tamanagung Kecamatan Cluring Kabupaten Banyuwangi Perspektif Hukum Ekonomi Islam

Kerjasama maro pengolahan sawah adalah kerjasama yang dilakukan oleh kedua belah pihak yakni antara pemilik sawah dan penggarap sawah di Desa Tamanagung Kecamatan Cluring Kabupaten Banyuwangi yang dilakukan dari masa ke masa dimana pemilik sawah hanya bermodalkan tanah saja, sedangkan penggarap sawah yang menanggung semua modal baik itu modal materi maupun modal materi. Mekanisme bagi hasil yang dilakukan dalam kerjasama tersebut adalah sistem bawon, bawon adalah upah dari biaya perawatan tanaman yang diambil dari keseluruhan hasil panen untuk diberikan kepada penggarap. Penggunaan sistem bawon dikarenakan sistem pembagian bawon sudah menjadi kebiasaan dari masyarakat Desa Tamanagung Kecamatan Cluring Kabupaten Banyuwangi. Sisa pengambilan tersebut yang akan dibagi hasil antara kedua belah pihak. Jadi semisal hasil panen mendapatkan 100\%, 20\% akan diberikan kepada penggarap sawah sebagai upah bawon, sisa $80 \%$ akan dibagi dua dengan pemilik sawah yang mana masing-masing pihak kebagian $40 \%$. Jika hasil panen mengalami keuntungan, maka keuntungan akan dibagikan antara kedua belah pihak. Begitu pula sebaliknya jika mengalami kerugian, maka kerugian ditanggung bersama. Pembagian hasil akan dibagi rata sesuai hasil akhir dan kesepakatan.

Hal ini sesuai dengan pernyataan praktek muzara'ah mengacu pada prinsip Profit and Loss Sharing System. Dimana hasil akhir menjadi patokan dalam praktek muzara'ah. Jika, hasil pertaniannya mengalami keuntungan, maka keuntunganya dibagi antara kedua belah pihak, yaitu petani pemilik sawah dan petani penggarap. Begitu pula sebaliknya, jika hasil pertaniannya mengalami kerugian, maka kerugiannya ditanggung bersama. Dalam prakteknya, muzara'ah sudah menjadi tradisi masyarakat petani di pedesaan khususnya di tanah Jawa, praktek ini biasa disebut dengan maro. Dari pembagian muzara'ah di atas bahwa bagi hasil dari penggarapan antara pemilik sawah dan penggarap bahwa pembagiannya akan dibagi rata sesuai pendapatan akhir (Wulandari, 2019)

Di Desa Tamanagung Kecamatan Cluring Kabupaten Banyuwangi kerjasama dalam bidang pertanian sudah biasa dilakukan. Masyarakat Desa Tamanagung Kecamatan Cluring Kabupaten Banyuwangi sangat terbantu dengan adanya 
Jurnal Ekonomi Syariah Darussalam

Vol I No I Agustus 2020, ISSN: 2745-8407

kerjasama maro pengolahan sawah karena masing-masing pihak yang melakukan kerjasama baik itu dari pemilik sawah dan penggarap sawah sama-sama diuntungkan dengan adanya kerjasama tersebut. Akad kerjasama sangat banyak tetapi yang melibatkan tanah atau sawah ada 3 antara lain akad muzara'ah, akad mukhabarah dan akad musaqah dimana pengertian dari ketiga akad tersebut antara lain.

Pengertian dari ke tiga akad tersebut adalah akad muzara'ah yaitu akad antara pemilik lahan dan pengelola lahan dengan bagi hasil seperdua, sepertiga, atau lebih tergantung kesepakatan di awal akan tetapi benihnya dari pemilik lahan. Akad mukhabarah yaitu akad antara pemilik lahan dan pengelola lahan dengan pembagian seperdua, sepertiga, atau lebih tergantung kesepakatan di awal dan bibit dari pengelola lahan. Akad musaqah adalah akad kerjasama dimana pemilik kebun menyerahkan kebunnya kepada orang yang lebih ahli untuk dikelola sedangkan hasil dari perkebunan dibagi sesuai dengan kesepakatan awal.

Jika ditarik kesimpulan dari ketiga akad diatas bahwa inti dari akad atau kerjasama adalah antarodin (saling rela), pengertian tidak hanya rela akan tetapi juga mengetahui berapa modal dan hasil dari kerjasama tersebut bisa dikatakan saling transparan dalam pembibitan, pengolahan, maupun hasil dari pertanian maupun perkebunan, sehingga diawal akad sudah dijelaskan berapa modal yang diperlukan dan berapa hasil yang akan dibagi setelah panen atau hasil dari persawahan atau perkebunan, sehingga kedua belah pihak atau lebih mengetahui berapa hasil yang didapatkan agar dikemudian hari tidak ada saling tuduh ataupun saling menfitnah.

Muzara'ah dan mukhabarah merupakan kerjasama antara pemilik sawah/ladang petani berdasarkan bagi hasil. Di Indonesia kerjasama lahan pertanian berdasarkan bagi hasil ini dikenal dengan istilah "Paroan Sawah", atau “Paduoan", atau Patigoan" (Rozalinda, 2017: 219).

Dapat dipahami bahwa mukhabarah dan muzara'ah ada persamaan dan ada pula perbedaan. Persamaannya ialah mukhabarah dan muzara'ah terjadi pada pada peristiwa yang sama, yaitu pemilik tanah menyerahkan tanahnya kepada orang lain untuk dikelola. Perbedaanya ialah pada modal, bila modal berasal dari pengelola, disebut mukhabarah, dan bila modal dikeluarkan dari pemilik tanah muzara'ah 
Jurnal Ekonomi Syariah Darussalam

Vol I No I Agustus 2020, ISSN: 2745-8407

(Suhendi, 2016:155-156).

Jika dikontekskan akad diatas kerjasama maro pengolahan sawah di Desa Tamanagung Kecamatan Cluring Kabupaten Banyuwangi yang mayoritas penduduknya bekerja sebagai petani mereka mempraktikkan kerjasama bagi hasil memakai akad mukhabarah dimana pemilik lahan hanya menyediakan lahan persawahan sedangkan penggarap yang memodali bibit dan menggarap sawah.

Hal ini sesuai dengan penelitian dari Restu Windi Utami (2017), yang berjudul “Tinjauan Hukum Islam Terhadap Sistem Maro Dalam Kerjasama Pengolahan Lahan Pertanian di Desa Tribuana Panggelan Banjarnegara", penelitian IAIN Purwokerto yang menyatakan hasil penelitiannya bahwa menurut hukum Islam adalah praktik sistem maro dalam kerjasama pengolahan lahan pertanian di Desa Tribuana Kecamatan Banjarnegara termasuk dalam akad mukhabarah.

Terdapat rukun dan syarat dalam kerjasama maro pengolahan sawah yang ada di Desa Tamanagung Kecamatan Cluring Kabupaten Banyuwangi, rukunnya adalah adanya perjanjian kerjasama maro pengolahan sawah sedangkan syaratnya adanya lahan yang diolah, ada orang yang menggarap dan ada pemilik sawah. Ada pula yang berpendapat rukun kerjasama maro pengolahan sawah tidak ada namun syaratnya kepercayaan, kejujuran, dan sama-sama saling menguntungkan tidak saling merugikan. Akan tetapi juga yang berpendapat bahwa rukun dan syarat kerjasama ini tidak ada. Walaupun sebenarnya ada rukun dan syarat dalam melakukan akad kerjasama bagi hasil. Adapun beberapa rukun dan syarat Menurut Hanafiyah, rukun muzara'ah ialah akad yaitu, ijab dan qabul antara pemilik dan pekerja dan secara rinci jumlah rukun-rukun dalam akad muzara'ah.

Jika dilihat dari syarat perolehan hasil tanaman, kerjasama maro pengolahan sawah yang dilakukan masyarakat Desa Tamanagung Kecamatan Cluring Kabupaten Banyuwangi bagian masing-masing pihak sudah disebutkan jumlahnya diawal perjanjian. Kerjasama maro pengolahan sawah yang dilakukan masyarakat Desa Tamanagung Kecamatan Cluring Kabupaten Banyuwangi adalah pemilik lahan memasrahkan tanahnya untuk dikelola orang lain. Pemilik lahan hanya meyedikan tanah saja, sedangkan penggarap sawah yang menanggung bibit serta pekerjaanya. Hal ini sesuai dengan pernyataan sebagai berikut. Adapun Bentukbentuk Muzara'ah dan Mukhabarah adalah sebagai berikut: 
Jurnal Ekonomi Syariah Darussalam

Vol I No I Agustus 2020, ISSN: 2745-8407

1. Lahan dan bibit dari pemilik lahan, sedangkan kerja dan peralatan pertanian dari petani. Bentuk akad muzara'ah dan mukhabarah seperti ini dibolehkan karena petani menerima hasil pertanian karena jasanya;

2. Pemilik lahan menyediakan lahan pertanian, bibit, peralatan pertanian dan kerja dari petani. Akad muzara'ah dan mukhabarah ini dibolehkan karena yang menjadi objek akad ini adalah manfaat lahan pertanian;

3. Lahan pertanian, bibit, dan peralatan pertanian dari pemilk lahan sedangkan kerja dari petani. Akad muzara'ah ini dibolehkan karena yang menjadi objek muzara'ah dan mukhabarah adalah jasa pertanian;

4. Lahan pertanian dan peralatan dari pemilik lahan sedangkan bibit dan kerja dari petani. Menurut Abu Yusuf dan Muhammad ibn Hasan Asy-Syaibani akad ini tidak sah, karena peralatan pertanian harus mengikut petani bukan pemilik lahan. Manfaat alat adalah untuk mengolah lahan pertanian.

Selang waktu melakukan kerjasama maro pengolahan sawah di Desa Tamanagung Kecamatan Cluring Kabupaten Banyuwangi ditetapkan di awal perjanjian sehingga jelas kapan berakhirnya kerjasama tersebut. Adapun berakhirnya akad muzara'ah, mukhabarah dan akad muzara'ah berakhir dalam keadaan sebagai berikut:

1. Habis batas waktu akad muzara'ah dan mukhabarah, apabila waktu akad berakhir, akad muzara'ah dan mukhabarah pun juga berakhir;

2. Salah seseorang yang melakukan akad meninggal dunia, menjadikan akad muzara'ah dan mukhabarah berakhir;

3. Akad fasakh disebabkan adanya udzur (halangan) yang menyebabkan terhalangnya kedua belah pihak melangsungkan akad muzara'ah dan mukhabarah, diantaranaya: Pertama pemilik lahan terbelenggu utang mengakibatkan dia pailit sehingga pertanian tersebut harus dijual. Kedua pemilik lahan mempunyai halangan, seperti harus melakukakan perjalanan sehingga tidak dapat melangsungkan akad (Rozalinda, 2017:223-224).

Berdasarkan pemaparan di atas penulis menyimpulkan bahwa kerjasama maro pengolahan sawah yang di lakukan masyarakat Desa Tamanagung Kecamatan Cluring Kabupaten Banyuwangi menggunakan sudah sesuai dengan rukun dan syarat yang telah disebutkan diantaranya adanya pemilik tanah dan penggarap, 
Jurnal Ekonomi Syariah Darussalam

Vol I No I Agustus 2020, ISSN: 2745-8407

tanah yang dikerjakan beserta manfaatnya serta ijab dan qabul. Praktik kerjasama maro pengolahan sawah di Desa Tamanagung Kecamatan Cluring Kabupaten Banyuwangi yakni pemilik sawah menyediakan sawah yang akan dikelola, sedangkan bibit dan pekerjaan menjadi tanggungan penggarap sawah. Mekanisme pembagian hasilnya pun sudah jelas ditetapkan di awal perjanjian. Bagian perolehan hasil tananaman pun sudah jelas diawal perjanjian.

\section{E. KESIMPULAN}

Berdasarkan pemaparan diatas dapat diambil kesimpulan bahwa "Kerjasama Maro Pengolahan Sawah dalam Perpektif Hukum Ekonomi Islam (Studi Kasus Di Desa Tamanagung Kecamatan Cluring Kabupaten Banyuwangi)" adalah sebagai berikut:

1. Kerjasama maro pengolahan sawah yang dimaksud dalam penelitian ini adalah kerjasama bagi hasil yang disepakati antara pemilik sawah dan penggarap sawah, di mana pemilik sawah tidak mengeluarkan modal sama sekali kecuali hanya tanah yang akan digarap. Semua modal akan dibebankan kepada penggarap sawah baik itu materi maupun tenaga. Mekanisme bagi hasil dalam kerjasama ini adalah total keseluruhan hasil panen akan dipotong bawon (biaya perawatan tanaman) yang berikan kepada penggarap sawah. Setelah pemotongan bawon dilakukan barulah sisa hasil tersebut dibagi dua atau di paro, yang mana kedua belah pihak menerima bagi hasil yang sama. Jika mendapat hasil 100\%, 20\% akan diberikan kepada penggarap sawah sebagai bawon tersebut, sisa $80 \%$ akan dibagi antara kedua belah pihak dimana masingmasing mendapat $40 \%$.

2. Kerjasama maro pengolahan sawah yang dilakukan masyarakat Desa Tamanagung Kecamatan Cluring Kabupaten Banyuwangi jika dikontekskan dalam hukum ekonomi Islam kerjasama dibidang pengolahan tanah, termasuk dalam akad mukhabarah yaitu akad kerjasama dibidang pertanian antara kedua belah pihak pemilik sawah dan penggarap sawah, di mana pemilik tanah hanya bermodal tanah saja, sedang bibit dan peralatan pengolahan sawah dibebankan kepada penggarap sawah. Hukum Islam yang bersumber pada agama Islam itu sendiri, memandang kerjasama maro pengolahan sawah diperbolehkan selama praktiknya tidak bertentangan dengan prinsip-prinsip syariah. Kerjasama maro 
Jurnal Ekonomi Syariah Darussalam

Vol I No I Agustus 2020, ISSN: 2745-8407

pengolahan sawah yang dilakukan masyarakat Desa Tamanagung juga sudah sesuai dengan rukun dan syarat akad mukhabarah seperti adanya pemilik sawah dan adanya penggarap sawah, objek berupa sawah yang digarap dan ijab qabul. Perolehan hasil tanaman dimana bagian dari masing-masing pihak sudah jelas ditetapkan diawal perjanjian.

\section{DAFTAR PUSTAKA}

Abdullah, Boedi dan Saebani, Beni Ahmad. 2014. Metode Peneitian Ekonomi Islam Muamalah. Bandung: CV Pustaka Setia.

Bustomi, Setyawan, Dkk. 2018. Akad Muzara'ah Pertanian Padi dalam Perspektif Ekonomi Syariah. Jurnal Fakultas Syariah dan Ekonomi Islam Institut Agama Islam Negeri Syeikh Nurjati Cirebon.

Darwis, Rizal. 2016. Sistem Bagi Hasil Pertanian pada Masyarakat Petani Kabupaten Gorontalo Perspektif Hukum Ekonomi Islam. Jurnal Fakultas Syariah IAIN Sultan Amain Gorontalo.

Departemen Agama RI. 2009. Al-Quran Karim. Jakarta.

Hak, Nurul. 2011. Ekonomi Islam Hukum Bisnis Syariah. Yogyakarta:Teras.

Moleong, Lexy J. 2011. Metode Penelitian Kualitatif. Bandung: PT Remaja Rosdakarya.

Muttalip, Abdul. 2015. Analisis Sistem Bagi Hasil Muzaraah dan Mukhabarah pada Usaha Tani Padi dan Implikasinya Terhadap Kesejahteraan Keluarga Petani Penggarap dan Pemilik Lahan di Kecamatan Praya Timur. Jurnal Artikel Islam.

Nurhayati, Yeni. 2015. Maro (Penggarapan Sawah) dalam Perspektif Ekonomi Islam (Studi Kasus Kesesuaian dengan Sistem Muzara'ah di Desa Atari Indah Kec. Lalembu Kab. Konawe Selatan. Penelitian Fakultas Ekonomi Dan Bisnis Islam Istitut Agama Islam Negeri Kendari.

Manan, Abdul. 2012. Hukum Ekonomi Syariah dalam Perspektif Kewenangan Peradilan Agama. Jakarta: Kencana.

Sugiyono. 2015. Metode Penelitian Kuantitatif, Kualitatif, dan R\&D. Bandung: Alpabeta.

Suhendi, Hendi. 2016. Fiqh Muamalah. Jakarta: PT. Raja Grafindo Persada.

Utami, R. W. 2017. Tinjauan Hukum Islam Terhadap Sistem Maro dalam Kerjasama Pengolahan Lahan Pertanian di Desa Tribuana Punggelan Banjarnegara. Penelitian Fakultas Hukum Syariah Institut Agama Islam Negeri (IAIN) Purwokerto.

Wulandari, L. S. 2019. Bagi Hasil dalam Sistem Penggarapan Sawah Maro dan Mrapat Perspektif Hukum Islam. Penelitian Fakultas Syariah Institut Agama Islam Negeri (IAIN) Surakarta.

Yin, Robert, K. 2015. Studi Kasus Desain \& Metode. Jakarta: PT. Raja Grafindo Persada. 